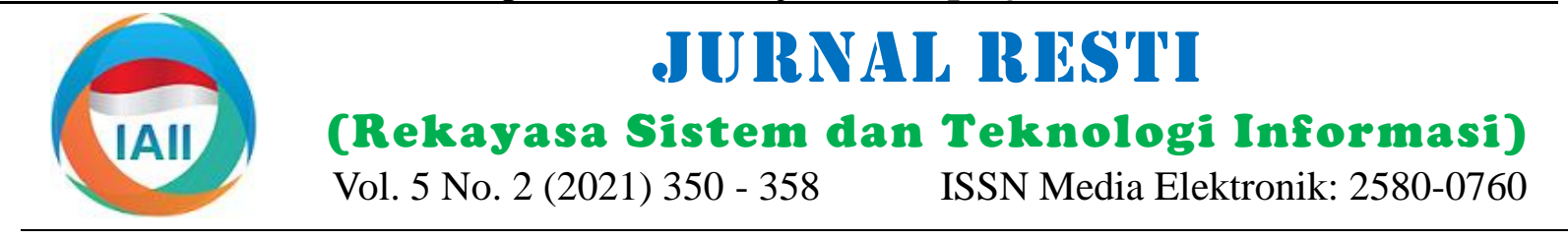

\title{
Pengambilan Keputusan Sistem Penjaminan Mutu Perguruan Tinggi menggunakan MOORA, SAW, WP, dan WSM
}

\author{
Sunardi ${ }^{1}$, Abdul Fadlil ${ }^{2}$, Ryan Fitrian Pahlevi ${ }^{3 *}$ \\ ${ }^{1,2}$ Program Studi Teknik Elektro, Fakultas Teknologi Industri, Universitas Ahmad Dahlan \\ ${ }^{3}$ Program Studi Magister Teknik Informatika, Fakultas Teknologi Industri, Universitas Ahmad Dahlan \\ ${ }^{1}$ sunardi@mti.uad.ac.id, ${ }^{2}$ fadlil@mti.uad.ac.id, ${ }^{3}$ ryan1708048031@webmail.uad.ac.id*
}

\begin{abstract}
Higher Education Quality Assurance (QA) is regulated in Quality Standards and the number of criteria as well as its relationship with the implementation of the Quality Assurance System (QAS), namely the Internal and External Quality Assurance System (IHSG). . The research is focused on analyzing 4 decision-making methods or Decision Support Systems (DSS) for QAS in MAC. The purpose of this study is to classify standard data and MAC criteria in business processes into a database that is integrated with the QAS decision-making method. The analysis was carried out on 4 multi-criteria decision-making methods that will be used in the QAS-MAC decision-making process, namely: Moora, SAW, WP, and WSM. These methods were tested on a quality standard database and then assessed by comparison, namely relevance, features, accuracy, precision, reliability, effectiveness, efficiency, strengths, and weaknesses. Decision Making Methods as a determinant of Business Process priorities become information for PTMA Leaders in predicting strategic activities. The value of the method analysis shows that 4 decision-making methods are Moora (75\%), SAW (75\%), WP (94\%), and WSM (94\%).
\end{abstract}

Keyword : decision-making methods, quality assurance system, decision support system, higher education, quality standard.

\begin{abstract}
Abstrak
Standar Mutu dan banyaknya kriteria dan keterkaitan dengan kegiatan pelaksanaan Sistem Penjaminan Mutu (SPM) yaitu Sistem Penjaminan Mutu Internal (SPMI) dan Sistem Penjaminan Mutu Eksternal (SPME) menjadi persoalan yang diangkat pada penelitian ini terkait Penjaminan mutu Perguruan Tinggi. Standar mutu merupakan standar yang ditetapkan oleh perguruan tinggi berdasarkan mutu dari pemerintah. Penelitian difokuskan pada analisis 4 algoritma pengambilan keputusan atau Sistem Pendukung Keputusan (SPK) untuk SPM di PTMA. Penelitian ini diadakan untuk menyelaraskan antara SPMI dan SPME dengan tujuan penelitian ini adalah untuk mengelompokkan data standar maupun kriteria PTMA dalam proses bisnis menjadi basis data yang diintegrasikan dengan metode pengambilan keputusan pada SPM. Analisis dilakukan terhadap 4 algoritma pengambilan keputusan multi kriteria untuk digunakan dalam proses pengambilan keputusan SPM PTMA, antara lain: MultiObjective Optimization on the basis of Rasio Analysis (MOORA); Simple Additive Weighting (SAW); Weighted Product (WP); dan Weighted Sum Model (WSM). Metode yang dilakukan adalah dengan menguji data yang ada berkaitan dengan basis data standar mutu untuk kemudian dinilai dengan variabel pembanding antar algoritma yaitu relevansi, ciri, akurasi, presisi, reliabilitas, efektivitas, efisiensi, kelebihan, dan kekurangan. Hasil dan analisis penelitian adalah metode pengambilan keputusan sebagai penentu prioritas Proses Bisnis menjadi informasi bagi Pimpinan PTMA dalam memprediksi kegiatan strategis. Nilai hasil analisis metode diperoleh bahwa 4 algoritma Pengambilan Keputusan yaitu mencapai Moora (75\%), SAW (75\%), WP (94\%), dan WSM (94\%).

Kata kunci : metode pengambilan keputusan, sistem penjaminan mutu, sistem pendukung keputusan, perguruan tinggi, standar mutu.
\end{abstract}




\section{Pendahuluan}

Kegiatan penyelenggaraan Perguruan Tinggi (PT) tidak dapat lepas dari pengelolaan atau manajemen dalam bentuk Sistem Penjaminan Mutu (SPM), baik itu Sistem Penjaminan Mutu Internal (SPMI) maupun Sistem Penjaminan Mutu Eksternal (SPME). Kegiatan SPMI yang memiliki kaitan erat dengan SPME dilakukan dalam suatu siklus Perencanaan, Pelaksanaan, Evaluasi, Pengendalian, dan Peningkatan (PPEPP). SPM yang dilakukan dengan rangkaian sistemik yang berkelanjutan menjadi persoalan yang cukup kompleks. Usaha pencapaian Standar Nasional Pendidikan Tinggi (SN-Dikti) maupun standar yang ditetapkan oleh PT dalam pelaksanaannya merupakan permasalahan tersendiri dalam penyelenggaraan PT.

Perguruan Tinggi Muhammadiyah/'Aisyiyah (PTMA) sebagai Perguruan Tinggi Swasta (PTS) di bawah naungan Persyarikatan Muhammadiyah tidak terlepas dari persoalan pelaksanaan SPM [1]. PTMA menetapkan satu dharma tambahan, yaitu Al-Islam dan Kemuhammadiyahan menjadikan PTMA memiliki kegiatan penyelenggaraan tidak lagi tiga (tri dharma: pendidikan, penelitian, dan pengabdian kepada masyarakat) melainkan menjadi empat (catur dharma).

Pencapaian mutu PTMA [2] dapat dijabarkan terlebih dahulu dari adanya stakeholder internal (mahasiswa, dosen, dan tenaga kependidikan) dan eksternal (pemerintah, sivitas akademika, pegawai, orang tua/wali mahasiswa, dewan penyantun/donatur, dan masyarakat). PTMA menetapkan kebijakan-kebijakan berdasarkan kebutuhan dari stakeholder yang dituliskan dalam peraturan tertinggi PT yaitu statuta sebagai anggaran dasar dan anggaran rumah tangga. Statuta PT atau dalam hal ini PTMA menggambarkan Bisnis Proses/Aras Kewenangan (Unsur Organ, Pimpinan/Rektorat, Senat, BPH, Persyarikatan Muhammadiyah melalui Majelis Pendidikan Tinggi dan Pengembangan (Diktilitbang) Pimpinan Pusat Muhammadiyah serta Tata Pamong dan
Tata Kelola. Kemudian dalam pelaksanaan kegiatan penyelenggaraan PT ditetapkan perencanaan, dalam bentuk dokumen strategis antara lain Rencana Jangka Panjang (RJP) atau Rencana Induk Pengembangan (RIPP), Rencana Jangka Menengah (RJM) atau Rencana Strategis (Renstra), Standar Mutu berdasarkan SN-Dikti dan SN-AIK yang memuat Indikator Kinerja Utama dan Tambahan, Rencana Jangka Pendek (RJPk) atau Rencana Operasional (Renop), dan Rencana Anggaran Pendapatan dan Belanja (RAPB).

Pada penyelenggaraan PT juga dilakukan sistem pengelolaan atau manajemen penjaminan mutu (SPMI, SPME, atau Manajemen Mutu) dengan siklus PPEPP (Perencanaan, Pelaksanaan, Evaluasi, Pengendalian, dan Peningkatan), EPP (Evaluasi, Penetapan, Pemantauan), atau PDCA (Plan, Do, Check, and Act).
Pengelolaan PTMA dapat digambarkan dalam 11 manajemen proses bisnis, yaitu [2]: 1) pendidikan, pengembangan suasana akademik, dan otonomi keilmuan; 2) administrasi umum dan keuangan; 3) perencanaan dan penjaminan mutu, serta sistem informasi; 4) organisasi dan kerjasama; 5) kemahasiswaan; 6) penelitian; 7) pengabdian kepada masyarakat; 8) al-islam dan kemuhammadiyahan; 9) sumber daya manusia; 10) sarana; dan 11) prasarana.

Metode pengambilan keputusan menjadi alat bantu dalam mengambil kebijakan. Penelitian ini dilakukan terhadap empat algoritma pengambilan keputusan dari beberapa multi kriteria untuk digunakan dalam proses pengambilan keputusan SPM PTMA, antara lain MultiObjective Optimization on the Basis of Rasio Analysis (MOORA) [3], Simple Additive Weighting (SAW) [3][4]); Weighted Product (WP) [5] [6] [3] [7] [8]), dan Weighted Sum Model (WSM) [3]. Algoritma-algoritma tersebut digunakan dan dilakukan analisis penggunaannya dalam penetapan ranking dari proses bisnis yang ditetapkan.

Penelitian ini dilakukan dengan kajian penelitian terdahulu yang memiliki relevansi dalam pembahasan. Beberapa penelitian tersebut antara lain:

Yuniarti Lestari, Sunardi, dan Abdul Fadlil [9] melakukan kegiatan pengambilan keputusan dalam SPK seleksi peserta didik baru menggunakan metode AHP dan Simple Additive Weighting (SAW). Penelitian tersebut diperoleh pembobotan kriteria menggunakan metode AHP sementara metode SAW digunakan untuk menentukan perangkingan alternatif.

Ryan Fitrian Pahlevi, Sunardi, dan Abdul Fadlil [10] menganalisis kebutuhan sistem informasi data warehouse. Penelitian tersebut dimaksudkan pada sistem penjaminan mutu internal dengan pembuatan data warehouse sebagai salah satu solusi untuk mendukung SPMI serta kriteria-kriteria akreditasi PT digunakan sebagai item-item pengumpulan data warehouse.

Sri Rahayu Astari, Rusydi Umar, dan Sunardi [11] menganalisis dan merancang sistem pengambilan keputusan dalam seleksi asisten laboratorium yang diharapkan membantu dalam pengembangan sistem pengambilan keputusan. penelitian tersebut menghasilkan sancangan sistem yang membantu pengolahan data dalam proses pengambilan keputusan seleksi asisten di Jurusan Teknik Informatika UPN

"Veteran" Yogyakarta

Dwika Assrani, Mesran, Ronda Deli Sianturi, Yuhandri, Akbar Iskandar [12] membangun SPK Pemilihan Guru Produktif Peserta Pelatihan Asesor Kompetensi LSP P1 SMK Swasta Dwiwarna Medan Menggunakan Metode The Extended Promethee II (EXPROM II). Hasil penelitian tersebut menunjukkan bahwa Metode

DOI: https://doi.org/10.29207/resti.v5i2.2977

Lisensi: Creative Commons Attribution 4.0 International (CC BY 4.0) 
EXPROM II memberikan keputusan yang lebih efektif 2. Metode Penelitian di banding metode SAW, WP, ataupun MOORA

Rusydi Umar, Abdul Fadlil, dan Rifqi Rahmatika AzZahra [13] mengelompokkan peminatan jurusan di SMK menggunakan metode Self Organizing Map (SOM) dengan mengacu angka yang dikelompokkan diklusterisasi dapat memudahkan calon siswa mengambil atau memilih jurusan.

Claudiu Brandas, Ciprian Panzaru, dan Florin Gheorghe Filip [14] menganalisis aplikasi pasar tenaga kerja menggunakan SPK berbasis data sehingga dihasilkan informasi dan pengetahuan tentang dinamika lowongan kerja dan keterampilan, konsentrasi pada unit wilayah dan kegiatan ekonomi diperoleh hasil penyajian hasil eksperimen dalam konteks pasar tenaga kerja.

Penelitian terkait WSM dilakukan dengan mengimplementasikan metode WP dan metode WSM kemudian dibandingkan dengan hasil perangkingan manual oleh perusahaan " $X$ " [15]. Hasil perbandingan dari penelitian ini ditinjau dari segi akurasi dan error. Berdasar kecepatan compile, metode WSM memerlukan sedikit waktu dibandingkan dengan metode WP.

Penelitian lain terkait WSM untuk Penentuan Peserta Jaminan Kesehatan Masyarakat (Mesran) serta penerapan salah satu Multi-Criteria Decision Making (MCDM) mampu untuk mengatasi kendala yang dihadapi pemerintah [16].

Penelitian ini diadakan sebagai bentuk penerapan SPM yang mampu menyelaraskan antara SPMI dan SPME sebagai langkah perhatian dan pelaksanaan penyelenggaraan penjaminan mutu suatu standar yang kompleks di PT. Kegiatan pengambilan keputusan dari banyaknya kriteria dan keterkaitan dalam kegiatan penjaminan mutu perlu dibuatkan metode bantu pengambilan keputusan.

Oleh sebab itu penelitian ini melakukan kegiatan analisis metode pengambilan keputusan multi kriteria dengan metode/algoritma yang dianalisis adalah MOORA, SAW, WP, dan WSM. Algoritma tersebut dipilih sebab termasuk dari multi kriteria, adapun masih ada algoritma lain yang termasuk multi kriteria, namun dalam penelitian ini dibatasi hanya dianalisis empat algoritma. Tujuan penelitian ini adalah untuk mengelompokkan data standar mutu dari penyelenggaraan PT maupun kriteria PTMA dalam proses bisnis menjadi basis data yang diintegrasikan dengan metode pengambilan keputusan (empat algoritma) yang diaplikasikan pada SPM kemudian dilakukan kegiatan analisis data menggunakan algoritma yang dipilih.

\subsection{Desain Sistem}

Sistem dibangun sebagai basis data serta alat bantu perhitungan dalam pengambilan keputusan. Desain sistem dibangun berdasarkan peta pemikiran SPM PTMA. Peta pemikiran (mind map) dibangun berdasarkan penyelenggaraan PTMA (Tabel 1). Tabel 1 dimaksudkan untuk menggambarkan kebutuhan penyelenggaraan PTMA yaitu statuta, dilanjut dengan perencanaan rencana (jangka panjang, menengah, dan pendek), kemudian diperinci dalam standar mutu, dan beberapa kebutuhan sumber daya, yaitu keuangan dan dokumen mutu.

Tabel 1. Peta pemikiran (mind map) dibangun berdasarkan penyelenggaraan PTMA

\begin{tabular}{|c|c|c|}
\hline No & Kebutuhan & Keterangan \\
\hline $\mathbf{1}$ & Statuta & $\begin{array}{l}\text { Bisnis Proses (Aras } \\
\text { Kewenangan) } \\
\text { Tata Pamong dan Tata Kelola }\end{array}$ \\
\hline 2 & $\begin{array}{l}\text { Rencana Induk } \\
\text { Pengembangan (RIP) } \\
\text { atau Rencana Jangka } \\
\text { Panjang (RJP) }\end{array}$ & Visi, Misi, Tujuan, dan Sasaran \\
\hline 3 & $\begin{array}{l}\text { Rencana Strategis } \\
\text { (Renstra) atau Rencana } \\
\text { Jangka Menengah } \\
\text { (RJM) }\end{array}$ & $\begin{array}{l}\text { Sasaran Strategis: Elemen atau } \\
\text { Butir Mutu, Indikator Kinerja, } \\
\text { Target Capaian atau Sasaran. }\end{array}$ \\
\hline 4 & Standar Mutu & $\begin{array}{l}\text { Standar Nasional Pendidikan } \\
\text { Tinggi dan Standar Al-Islam } \\
\text { dan Kemuhammadiyahan. } \\
\text { Standar-standar tersebut } \\
\text { dijabarkan dalam catur dharma } \\
\text { pendidikan tinggi masing- } \\
\text { masing memiliki indikator } \\
\text { kinerja utama dan indikator } \\
\text { kinerja tambahan }\end{array}$ \\
\hline 5 & $\begin{array}{l}\text { Rencana Operasional } \\
\text { (Renop) atau Rencana } \\
\text { Jangka Pendek (RJPk) }\end{array}$ & $\begin{array}{l}\text { Sebagai perencanaan untuk } \\
\text { operasional tiap tahun akademik }\end{array}$ \\
\hline 6 & $\begin{array}{l}\text { Rencana Anggaran } \\
\text { Pendapatan dan } \\
\text { Belanja (RAPB) }\end{array}$ & $\begin{array}{l}\text { Sebagai bagian kebutuhan } \\
\text { sumber daya keuangan dalam } \\
\text { perencanaan tiap Renop ( } 1 \\
\text { tahun) }\end{array}$ \\
\hline 7 & Dokumen Mutu & $\begin{array}{l}\text { Terdiri dari dokumen induk; } \\
\text { kebijakan; manual; prosedur } \\
\text { sistem/standar operasional } \\
\text { prosedur; instruksi kerja; } \\
\text { formulir; atau dokumen } \\
\text { rekaman monitoring dan } \\
\text { evaluasi }\end{array}$ \\
\hline
\end{tabular}

Peta pemikiran dalam proses pencapaian Visi, Misi, Tujuan, dan Sasaran (VMTS) semata-mata tidak lepas dari beberapa unsur yang antara lain adalah berdasarkan regulasi pemerintah yang diturunkan dalam statuta PT dan penetapan standar mutu dalam perencanaan yang kemudian terdapat tata pamong dan kelola PTMA dan kebutuhan sumber daya berupa keuangan, sarana, dan prasarana. 
Kriteria didefinisikan berdasarkan Parameter, Kriteria, dan/atau Variabel yang dibutuhkan untuk mendapatkan rangking akhir. Ranking akhir yang diperoleh adalah urutan rangking dari Proses Bisnis.

SPK dilakukan dengan langkah mendefinisikan kriteria, proses pengambilan keputusan, dan selanjutnya diperoleh ranking dan hasil akhir (Gambar 1). Konsep sistem kemudian diterapkan dalam sistem manajemen penjaminan mutu PTMA menggunakan software Microsoft Excel dengan membangun basis data standar mutu (Gambar 2) sebagai penghubung penyelenggaraan PTMA serta kriteria pencapaian VMTS yang diintegrasikan dengan metode pengambilan keputusan.

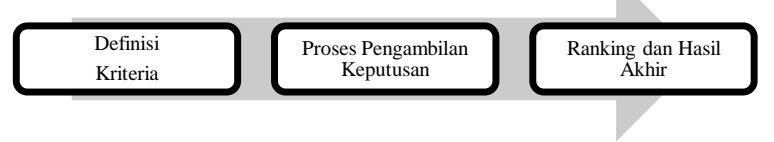

Gambar 1. Konsep sistem pendukung keputusan

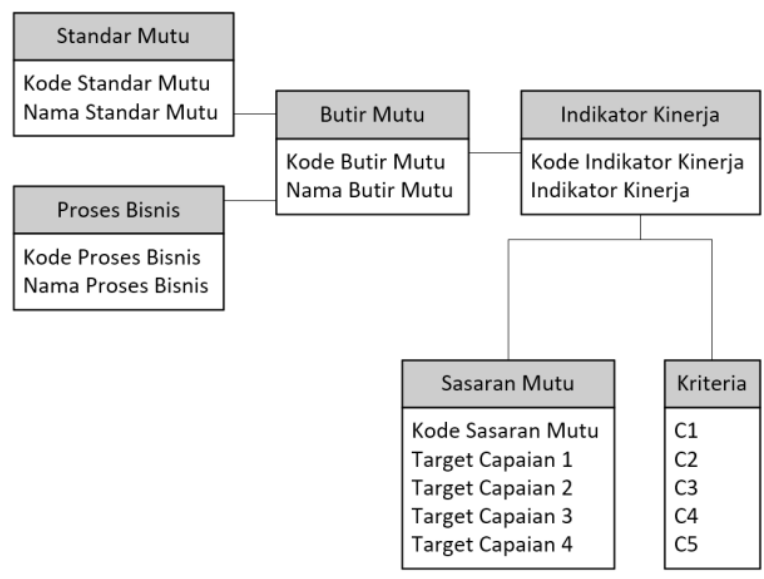

Gambar 2. Basis data standar mutu

Pengujian relevansi metode dilakukan dengan mendefinisikan parameter, kriteria, dan/atau variabel yang akan digunakan pada rumus/formula/persamaan dari objek penelitian atau metode pengambilan keputusan yang diuji coba. Parameter, kriteria, dan/atau variabel yang muncul dari basis data yang telah dibangun dapat dilihat pada Tabel 2 .

Analisis dilakukan dengan mendapatkan nilai dari kriteria yang ditetapkan (Tabel 2) dengan penjelasan bahwa siklus PPEPP dalam pelaksanaan penjaminan mutu dengan nilai bobot berdasarkan bobot pelaksanaan siklus. Kriteria yang ditentukan merupakan siklus dari kegiatan SPMI [17] antara lain: 1) penetapan standar PT; 2) pelaksanaan standar PT; 3) evaluasi pelaksanaan standar PT; 4) pengendalian pelaksanaan standar PT; dan 5) peningkatan standar PT. Kegiatan-kegiatan tersebut kemudian ditetapkan menjadi kriteria yang dinyatakan dengan $\mathrm{C} 1$ hingga $\mathrm{C} 5$.
Tabel 2. Parameter, kriteria, dan/atau variabel standar mutu

\begin{tabular}{llccc}
\hline Nama Kriteria & $\begin{array}{c}\text { Analisis } \\
\text { GAP }\end{array}$ & Nilai Bobot & Kriteria \\
\hline C1 & Perencanaan & 3 & 0,20 & Benefit \\
C2 & Pelaksanaan & 5 & 0,40 & Benefit \\
C3 & Evaluasi & 4 & 0,25 & Benefit \\
C4 & Pengendalian & 2 & 0,10 & Benefit \\
C5 & Peningkatan & 1 & 0,05 & Benefit \\
\hline
\end{tabular}

GAP [5] yang merupakan nilai kesenjangan bernilai -5 hingga 5 [6] dari antar kinerja suatu variabel atau dalam hal ini adalah kriteria dilakukan analisis GAP [3] dari perencanaan (C1) ditetapkan bernilai 3 yang berarti bahwa memiliki kelebihan pada tingkat 3. Analisis GAP dari pelaksanaan $(\mathrm{C} 2)$ ditetapkan bernilai 5 yang berarti bahwa memiliki kelebihan pada tingkat 5. analisis GAP dari evaluasi (C3) ditetapkan bernilai 4 yang berarti bahwa memiliki kelebihan pada tingkat 4. analisis GAP dari pengendalian (C4) ditetapkan bernilai 2 yang berarti bahwa memiliki kelebihan pada tingkat 2. Kemudian analisis GAP dari perencanaan (C5) ditetapkan bernilai 1 yang berarti bahwa memiliki kelebihan pada tingkat 1 . [7]

Nilai bobot yang merupakan nilai dari masing-masing bobot 5 kriteria ditetapkan dengan nilai bobot keseluruhan adalah bernilai 1 (100\%). Perencanaan merupakan kegiatan awal dari suatu penetapan standar PT, ditetapkan memiliki bobot 0,20 (20\%). Pelaksanaan merupakan kegiatan implementasi standar yang telah ditetapkan, menjadikan kegiatan pelaksanaan adalah kegiatan yang memiliki porsi bobot yang besar. Hal ini menjadi dasar penetapan bobot dari pelaksanaan adalah $0,40(40 \%)$. Kegiatan pelaksanaan yang telah berjalan kemudian dilakukan kegiatan evaluasi serta monitoring pencapaian dari perencanaan dan pelaksanaan standar PT, dan bobot evaluasi bernilai 0,25 (25\%). Pengendalian merupakan kegiatan lanjutan dari evaluasi yang telah dilakukan, dimaksudkan untuk mengendalikan standar dari temuan temuan positif maupun negatif, dan kegiatan pengendalian diberikan nilai bobot sebesar $0,10(10 \%)$. Peningkatan merupakan penetapan dari tindak lanjut siklus-siklus sebelumnya agar kemudian dilakukan tindakan perencanaan standar PT kembali, peningkatan diberi nilai bobot 0,05 (5\%).

Parameter, kriteria, dan/atau variabel standar mutu ditetapkan dari semua kriteria adalah benefit [3] yang berarti bahwa berguna atau bermanfaat dan memang diperlukan dalam siklus SPM baik itu SPMI ataupun SPME.

\subsection{Langkah Pengujian Metode}

Data yang dikumpulkan dianalisis menggunakan metode dengan tujuan mendapatkan hasil yang diharapkan sesuai hipotesis penelitian. Analisis data (analyze data) dilakukan berdasarkan desain penelitian yang lebih spesifik terkait analisis. Metode yang digunakan dalam penelitian ini adalah metode eksperimental dengan

DOI: https://doi.org/10.29207/resti.v5i2.2977

Lisensi: Creative Commons Attribution 4.0 International (CC BY 4.0) 
desain faktorial yaitu kegiatan pengujian serta analisis $Y_{i}=\sum_{j=1}^{g} W_{j} X_{i j}^{*}-\sum_{j=g+1}^{n} W_{j} W_{i j}^{*}$

membandingkan banyak metode pengambilan keputusan sebagai objek penelitian dan variabel pembanding antar algoritma antara lain: relevansi, ciri [3]. metode, akurasi, presisi, reliabel, efektivitas, efisiensi, kelebihan, dan kekurangan [7].

Tabel 3. Skala skor penilaian parameter pembanding

\begin{tabular}{cc}
\hline Skala & Kualitas \\
\hline $\mathbf{0}$ & Tidak dinilai \\
$\mathbf{1}$ & Sangat kurang \\
$\mathbf{2}$ & Kurang \\
$\mathbf{3}$ & Baik \\
$\mathbf{4}$ & Sangat Baik \\
\hline
\end{tabular}

Variabel pembanding antar algoritma digunakan sebagai kriteria penilaian untuk algoritma pengambilan keputusan yang diuji coba yaitu dengan cara memberi skor penilaian dari nilai 0 hingga 4 , dengan arti skala skor penilaian dapat dilihat pada Tabel 3. Skor 0 dengan kualitas "Tidak dinilai" merupakan nilai terendah dan bermakna belum dianjurkan.

MOORA adalah algoritma yang mengoptimalkan dua atau lebih atribut yang saling bertentangan secara bersamaan [3]. Algoritma ini diurutkan dengan langkah awal adalah dengan menginputkan nilai kriteria di mana nilai kriteria pada suatu alternatif adalah nilai tersebut nantinya akan diproses dan hasilnya akan menjadi keputusan. Nilai kriteria kemudian diubah menjadi matriks keputusan. Matriks keputusan berfungsi sebagai pengukuran kinerja dari alternatif I th pada atribut $\mathrm{J}$ th, $\mathrm{M}$ adalah alternatif dan $\mathrm{n}$ adalah jumlah atribut dan kemudian sistem rasio dikembangkan. Setiap kinerja dari sebuah alternatif pada sebuah atribut dibandingkan dengan penyebut yang merupakan wakil untuk semua alternatif dari atribut tersebut. Bentuk matriks yang dimaksud dapat dilihat pada rumus 1 .

$X=\left[\begin{array}{lll}x_{11} & x_{12} & x_{1 n} \\ x_{21} & x_{22} & x_{2 n} \\ x_{m 1} & x_{m 2} & x_{m n}\end{array}\right]$

dengan $x$ adalah elemen matrix [3].

Proses selanjutnya adalah normalisasi pada algoritma MOORA bertujuan untuk menyatukan setiap element matriks sehingga element pada matriks memiliki nilai yang seragam. Normalisasi dilakukan dengan menggunakan rumus 2 .

$X_{i j}=\frac{X_{i j}}{\sqrt{\left[\sum_{i=1}^{m} X_{i j}^{2}\right]}}$

dengan $x$ adalah elemen matrix [3].

Normalisasi yang telah dilakukan kemudian dilanjut dengan langkah mengurangi nilai maxmax dan minmax untuk menandakan bahwa sebuah atribut lebih penting itu bisa dikalikan dengan bobot yang sesuai (koefisien signifikasi) dengan menggunakan rumus 3 . dengan $W$ adalah bobot, dan $Y_{i}$ adalah nilai preferensi [3].

Nilai akhir dari perhitungan menggunakan rumus 3 selanjutnya digunakan untuk menentukan ranking dari hasil perhitungan MOORA dengan rangking tertinggi adalah yang memiliki nilai preferensi tertinggi.

SAW bisa juga disebut sebagai metode penjumlahan terbobot yaitu mencari penjumlahan terbobot dari rating kinerja pada setiap alternatif pada semua atribut [3]-[4]. Algoritma ini dilakukan dengan langkah, mendefinisikan terlebih dahulu kriteria-kriteria yang di jadikan sebagai tolak ukur penyelesaian masalah. Tahap normalisasi dilakukan pada setiap alternatif pada setiap atribut dengan cara menghitung nilai rating kinerja menggunakan rumus 4 .

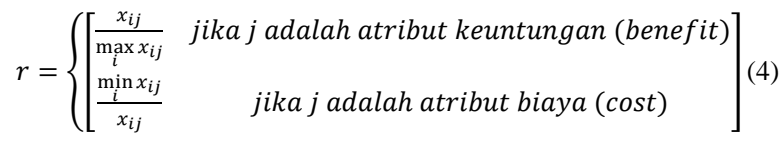

dengan $r$ adalah rating kinerja [3]-[4].

Langkah selanjutnya adalah menghitung nilai bobot preferensi pada setiap alternatif dengan menggunakan rumus 5.

$V_{i}=\sum_{j=1}^{n} w_{j} r_{i j}$

dengan $V_{i}$ adalah nilai bobot preferensi dari setiap alternatif, $w_{j}$ adalah nilai bobot kriteria, $r_{i j}$ adalah nilai rating kerja [3]-[4].

Tahap akhir dari algoritma SAW adalah melakukan perangkinan dengan nilai rangking tertinggi adalah yang memiliki nilai preferensi tertinggi.

WP merupakan metode pengambilan keputusan dengan cara perkalian untuk menghubungkan rating atribut, di mana rating setiap atribut harus dipangkatkan dulu dengan bobot atribut yang bersangkutan untuk mendapatkan hasilnya [3]-[8]. Algoritma ini dimulai dengan mendefinisikan terlebih dahulu kriteria-kriteria yang akan dijadikan sebagai tolak ukur penyelesaian masalah kemudian langkah menormalisasikan setiap nilai alternatif (nilai vektor) dilakukan dengan menggunakan rumus 6 .

$S_{i}=\prod_{j=1}^{n} x_{i j}{ }^{w_{j}}$

dengan $S$ adalah normalisasi nilai vektor, $x$ adalah nilai vektor, dan $w$ adalah bobot [3]-[8].

Nilai bobot preferensi dihitung pada setiap alternatif menggunakan rumus 7 dan kemudian dapat dilakukan perankingan dengan nilai rangking tertinggi adalah yang memiliki nilai bobot preferensi tertinggi $(V)$.

$V_{i}=\frac{s_{i}}{\sum s_{i}}=\frac{\prod_{j=1}^{n} x_{i j}{ }^{w_{j}}}{\prod_{j=1}^{n} x_{i j}{ }^{w_{j}}}$ 
dengan $V$ adalah bobot preferensi, $S$ adalah normalisasi bobot kriteria untuk perhitungan urutan ranking Proses nilai vektor, $x$ adalah nilai vektor, dan $w$ adalah bobot Bisnis menggunakan algoritma pengambilan keputusan [3]-[8].

Moora, SAW, WP, dan WSM. Perhitungan ranking

WSM yang merupakan algoritma pendukung keputusan adalah salah satu algoritma yang sangat sederhana dan mudah dipahami penerapannya karena hanya melakukan perkalian di antara bobot kriteria dan nilai alternatif, dengan langkah sebagai berikut [3]: mengidentifikasi kriteria dan alternatif yang digunakan dalam penyelesaian masalah kemudian dilakukan perhitungan WSM-Score menggunakan rumus 8 kemudian dilakukan perankingan.

$A_{i}^{W S M-S c o r e}=\sum_{j=1}^{n} w_{j} x_{i j}$

dengan $n$ adalah jumlah kriteria, $w_{j}$ adalah bobot dari setiap kriteria, dan $x_{i j}$ adalah nilai matrik $x$ [3].

\section{3. Hasil dan Pembahasan}

\subsection{Penggunaan Sistem}

SPM sebagai sistem untuk menjamin mutu PT digunakan dengan teknis menyelaraskan antara standar yang ditetapkan oleh pemerintah dengan standar yang ditetapkan oleh perguruan tinggi yaitu standar mutu. Hasil penelitian berupa basis data standar mutu disusun dengan cara standar mutu yang diperinci dalam butir mutu untuk selanjutnya ditetapkan indikator kinerja serta target capaian yang dikelompokkan berdasarkan 11 proses bisnis PTMA. Basis data diintegrasikan dengan formula matematis SPK untuk menentukan prioritas proses bisnis untuk informasi bagi pimpinan PTMA dalam memprediksi kegiatan strategis.

\subsubsection{Hasil Penggunaan Sistem}

Standar mutu diperinci dalam butir mutu untuk selanjutnya ditetapkan indikator kinerja serta target capaian serta pengelolaan/manajemen PT standar mutu yang telah dinilai kinerja pencapaiannya dengan pengisian kriteria PPEPP dikelompokkan berdasarkan proses bisnis menjadi data pivot sesuai dengan proses bisnis yang akan dinilai. Standar mutu ditetapkan PT yang kemudian dipecah menjadi butir-butir mutu yang masing-masing memiliki indikator kinerja. Indikator kinerja merupakan parameter mutu kegiatan yang dilakukan di PT dan dapat ditentukan lima macam target capaian dengan skor $0,1,2,3$, dan 4 . Hasil pengisian kinerja pencapaian secara subjektif disajikan pada Tabel 4 yang diperoleh dengan cara memasukkan skor $(0$ hingga 4) pada masing-masing indikator kinerja dengan target capaian yang direncanakan. Angka-angka tersebut diperoleh dengan menghitung nilai rata-rata dari masing-masing proses bisnis (standar mutu yang dikelompokkan) berdasarkan masing-masing siklus PPEPP. Target capaian tersebut merupakan hasil penilaian internal dari PT. Skor yang telah diperoleh pada Tabel 4 selanjutnya digunakan untuk menghitung menggunakan metode pengambilan keputusan dengan memasukkan nilai pada Tabel 2 dan Tabel 4 ke dalam rumus 1 hingga rumus 8 .

Tabel 4. Pencapaian indikator kinerja (subjektif)

\begin{tabular}{|c|c|c|c|c|c|c|}
\hline No. & $\begin{array}{l}\text { Proses } \\
\text { Bisnis }\end{array}$ & 宽 & 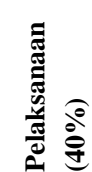 & 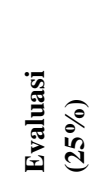 & 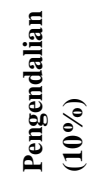 & م \\
\hline 1. & $\begin{array}{l}\text { Pendidikan, } \\
\text { Pengembangan } \\
\text { Suasana } \\
\text { Akademik dan } \\
\text { Otonomi } \\
\text { Keilmuan }\end{array}$ & 0,990 & 0,733 & 0,631 & 0,724 & 0,879 \\
\hline 2. & $\begin{array}{l}\text { Administrasi } \\
\text { Umum dan } \\
\text { Keuangan }\end{array}$ & 0,901 & 0,605 & 0,485 & 0,575 & 0,625 \\
\hline 3. & $\begin{array}{l}\text { Perencanaan dan } \\
\text { Penjaminan } \\
\text { Mutu, serta } \\
\text { Sistem Informasi }\end{array}$ & 0,834 & 0,440 & 0,281 & 0,409 & 0,643 \\
\hline 4. & $\begin{array}{l}\text { Organisasi dan } \\
\text { Kerjasama }\end{array}$ & 0,914 & 0,575 & 0,430 & 0,571 & 0,578 \\
\hline 5. & Kemahasiswaan & 0,847 & 0,799 & 0,764 & 0,764 & 0,579 \\
\hline 6. & Penelitian & 0,998 & 0,170 & 0,136 & 0,080 & 0,832 \\
\hline 7. & $\begin{array}{l}\text { Pengabdian } \\
\text { kepada } \\
\text { Masyarakat }\end{array}$ & 0,998 & 0,251 & 0,293 & 0,240 & 0,864 \\
\hline 8. & $\begin{array}{l}\text { Al-Islam dan } \\
\text { Kemuhammadiy } \\
\text { ahan }\end{array}$ & 1,000 & 0,418 & 0,336 & 0,364 & 0,369 \\
\hline 9. & $\begin{array}{l}\text { Sumber Daya } \\
\text { Manusia }\end{array}$ & 0,861 & 0,476 & 0,397 & 0,488 & 0,754 \\
\hline 10. & Sarana & 0,898 & 0,442 & 0,361 & 0,414 & 0,879 \\
\hline 11. & Prasarana & 0,995 & 0,319 & 0,309 & 0,351 & 0,981 \\
\hline
\end{tabular}

\subsubsection{Hasil Analisis Data}

Hasil dari analisis data dan penggunaan software microsoft Excel yang telah dilakukan menjadi bahan untuk kegiatan uji coba dengan nilai skor variabel pembanding antar algoritma, yaitu relevansi, ciri algoritma, akurasi, presisi, reliabilitas, efektivitas, efisiensi, kelebihan, dan kekurangan. Skor penilaian (Tabel 5) diperoleh dengan menghitung nilai rata-rata masing-masing skor algoritma (Tabel 6 hingga Tabel 14) dikali $100 \%$ dan diperoleh nilai algoritma dalam skor persentase.

Hasil penelitian pada Tabel 5 dan diagram pada Gambar 3 diperoleh dengan menghitung nilai rata-rata skor dikali $100 \%$ dan menghasilkan bahwa persentase algoritma MOORA adalah sebesar $75 \%$, SAW adalah $75 \%$, WP adalah 94\%, dan WSM sebesar $94 \%$.

Tabel 5. Skor penilaian dalam pengambilan keputusan

\begin{tabular}{cllc}
\hline No. & Kode & \multicolumn{1}{c}{ Algoritma } & Persentase (\%) \\
\hline 1. & Moora & Moora & 75 \\
2. & SAW & Simple Additive Weighting & 75 \\
3. & WP & Weighted Product & 94 \\
4. & WSM & Weighted Sum Model & 94 \\
\hline
\end{tabular}

DOI: https://doi.org/10.29207/resti.v5i2.2977

Lisensi: Creative Commons Attribution 4.0 International (CC BY 4.0) 


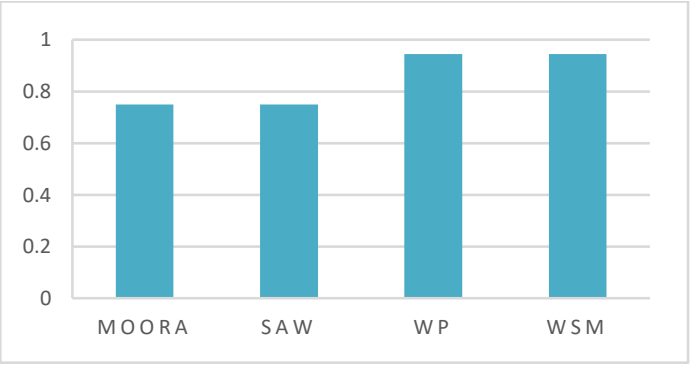

Gambar 3. Diagram hasil analisis algoritma pengambilan keputusan

\subsection{Pengujian Algoritma}

Hasil penelitian pada Tabel 5 dan Gambar 3 adalah jawaban bahwa metode pengambilan keputusan dapat digunakan dalam menetapkan proses bisnis. Proses Bisnis yang mampu diurutkan dalam rangking dapat digunakan untuk membantu pimpinan PTMA dalam memprediksi kegiatan strategis maupun kinerja.

Berikut disajikan pengujian algoritma berdasarkan Tabel 5 skor penilaian yang didapatkan adalah pencapaian algoritma diperoleh berdasarkan perhitungan dari penilaian relevansi, ciri algoritma, akurasi, presisi, reliabel, efektivitas, efisiensi, kelebihan, dan kekurangan algoritma pengambilan keputusan yang digunakan. Nilai skor diperoleh dalam uji coba secara subjektif penilaian algoritma.

\subsubsection{Relevansi}

Relevansi dimaksudkan untuk menguji keterkaitan antara metode pengambilan keputusan yang diteliti dengan SPM. Hasil pengujian relevansi dapat dilihat pada Tabel 6.

Tabel 6. Relevansi dalam pengambilan keputusan

\begin{tabular}{cclc}
\hline No. & Kode & \multicolumn{1}{c}{ Pembahasan } & Skor \\
\hline $\mathbf{1}$ & Moora & $\begin{array}{l}\text { Parameter, Kriteria, dan/atau Variabel } \\
\text { mampu didefinisikan }\end{array}$ & 4 \\
$\mathbf{2}$ & SAW & $\begin{array}{l}\text { Parameter, Kriteria, dan/atau Variabel } \\
\text { mampu didefinisikan }\end{array}$ & 4 \\
$\mathbf{3}$ & WP & $\begin{array}{l}\text { Parameter, Kriteria, dan/atau Variabel } \\
\text { mampu didefinisikan }\end{array}$ & 4 \\
$\mathbf{4}$ & WSM & $\begin{array}{l}\text { Parameter, Kriteria, dan/atau Variabel } \\
\text { mampu didefinisikan }\end{array}$ & 4 \\
\hline
\end{tabular}

\subsubsection{Ciri Algoritma}

Ciri algoritma dimaksudkan untuk menilai tanda khas dari metode yang membedakan dengan algoritma yang lain. Hasil perbandingan ciri algoritma dapat dilihat pada Tabel 7.

Tabel 7. Ciri algoritma pengambilan keputusan

\begin{tabular}{rrlc}
\hline No. & Kode & \multicolumn{1}{c}{ Pembahasan } & Skor \\
\hline 1 & Moora & $\begin{array}{l}\text { Penetapan nilai bobot kriteria selain } \\
\text { ditentukan dengan Nilai Bobot juga }\end{array}$ & 1 \\
& & terdapat penilaian kriteria Benefit serta & \\
& & Cost menjadikan perhitungan nilai akhir & \\
& ada proses pengurangan nilai Max & \\
& dikurangi nilai Min. Hal ini memang & \\
& menjadi ciri algoritma Moora dalam & \\
& SPM PTMA digunakan untuk menilai &
\end{tabular}

\begin{tabular}{|c|c|c|c|}
\hline No. & Kode & Pembahasan & Skor \\
\hline 2 & SAW & $\begin{array}{l}\text { nilai minus, walaupun Proses Bisnis } \\
\text { ditetapkan tidak bernilai minus. } \\
\text { Penetapan nilai bobot kriteria selain } \\
\text { ditentukan dengan Nilai Bobot juga } \\
\text { terdapat penilaian kriteria Benefit serta }\end{array}$ & 1 \\
\hline & & $\begin{array}{l}\text { Cost. Hal ini memang menjadi ciri } \\
\text { algoritma SAW dalam SPM PTMA } \\
\text { digunakan untuk menilai nilai minus, } \\
\text { walaupun proses bisnis ditetapkan tidak } \\
\text { bernilai minus. }\end{array}$ & \\
\hline 3 & WP & $\begin{array}{l}\text { Proses pengurutan ranking dari nilai } \\
\text { preferensi yang tertinggi adalah dengan } \\
\text { menormalisasi menggunakan } \\
\text { perhitungan perpangkatan dan penilaian } \\
\text { vektor dengan mengalikan hasil } \\
\text { normalisasi. }\end{array}$ & 4 \\
\hline 4 & WSM & $\begin{array}{l}\text { Alternatif yang digunakan dapat berupa } \\
\text { nilai } 0 \text { hingga } 1\end{array}$ & 4 \\
\hline
\end{tabular}

\subsubsection{Akurasi}

Akurasi algoritma dimaksudkan untuk menilai tingkat kedekatan hasil pengukuran kuantitas algoritma terhadap nilai yang sebenarnya. Hasil akurasi dapat dilihat pada Tabel 8.

Tabel 8. Akurasi dalam pengambilan keputusan

\begin{tabular}{|c|c|c|c|}
\hline No. & Kode & Pembahasan & Skor \\
\hline 1 & Moora & $\begin{array}{l}\text { Penetapan nilai minus berisiko } \\
\text { perbedaan perhitungan di tiap proses } \\
\text { bisnis }\end{array}$ & 2 \\
\hline 2 & SAW & $\begin{array}{l}\text { Normalisasi setiap alternatif menjadikan } \\
\text { algoritma ini rentan terhadap } \\
\text { penyimpangan hasil perhitungan }\end{array}$ & 2 \\
\hline 3 & WP & $\begin{array}{l}\text { Penggunaan operasi pangkat berisiko } \\
\text { hasil perhitungan yang menyimpang bila } \\
\text { tidak dilakukan perhitungan secara } \\
\text { detail }\end{array}$ & 3 \\
\hline 4 & WSM & $\begin{array}{l}\text { Perhitungan nilai alternatif dapat } \\
\text { dilakukan secara persentase, mengurangi } \\
\text { risiko perhitungan yang panjang }\end{array}$ & 4 \\
\hline
\end{tabular}
3.2.4. Presisi

Presisi algoritma dimaksudkan untuk menilai tingkat sejauh mana pengulangan pengukuran menggunakan metode pengambilan keputusan tidak berubah memberikan hasil yang sama. Pembahasan dan penilaian kepresisian metode pengambilan keputusan dalam pemakaiannya untuk SPM PTMA dapat dilihat pada Tabel 9.

\begin{tabular}{|c|c|c|c|}
\hline No. & Kode & Pembahasan & Skor \\
\hline 1 & Moora & $\begin{array}{l}\text { Bila formula diinputkan secara benar, } \\
\text { hasil diperoleh kepresisian tinggi dengan } \\
\text { toleransi yang kecil }\end{array}$ & 4 \\
\hline 2 & SAW & $\begin{array}{l}\text { Bila formula diinputkan secara benar, } \\
\text { hasil diperoleh kepresisian tinggi dengan } \\
\text { toleransi yang kecil }\end{array}$ & 4 \\
\hline 3 & WP & $\begin{array}{l}\text { Bila formula diinputkan secara benar, } \\
\text { hasil diperoleh kepresisian tinggi dengan } \\
\text { toleransi yang kecil }\end{array}$ & 4 \\
\hline 4 & WSM & $\begin{array}{l}\text { Bila formula diinputkan secara benar, } \\
\text { hasil diperoleh kepresisian tinggi dengan } \\
\text { toleransi yang kecil }\end{array}$ & 4 \\
\hline
\end{tabular}




\subsubsection{Reliabel}

Reliabel dimaksudkan untuk menilai algoritma mempunyai atau mendatangkan hasil yang sama pada setiap percobaan yang berhasil artinya bila digunakan berulang akan memberikan hasil pengukuran yang tetap akurat dan presisi. Pembahasan dan penilaian reliabilitas penggunaan metode pengambilan keputusan dalam SPM PTMA dapat dilihat pada Tabel 10.

Tabel 10. Reliabilitas dalam pengambilan keputusan

\begin{tabular}{rclc}
\hline No. & Kode & \multicolumn{1}{c}{ Pembahasan } & Skor \\
\hline $\mathbf{1}$ & Moora & $\begin{array}{l}\text { dapat digunakan secara berulang-ulang } \\
\text { dengan nilai alternatif kriteria yang } \\
\text { diubah-ubah } \\
\text { dapat digunakan secara berulang-ulang } \\
\text { dengan nilai alternatif kriteria yang } \\
\text { diubah-ubah } \\
\text { dapat digunakan secara berulang-ulang } \\
\text { dengan nilai alternatif kriteria yang } \\
\text { diubah-ubah } \\
\text { dapat digunakan secara berulang-ulang } \\
\text { dengan nilai alternatif kriteria yang } \\
\text { diubah-ubah }\end{array}$ & 4 \\
\hline
\end{tabular}

\subsubsection{Efektivitas}

Efektivitas algoritma dimaksudkan untuk menilai hasil pengukuran algoritma mampu memberikan hasil sesuai dengan tujuan yang ingin dicapai yaitu mengurutkan prioritas proses bisnis kegiatan SPM di PTMA. Pembahasan dan penilaian tingkat efektivitas metode pengambilan keputusan dalam SPM PTMA dapat dilihat pada Tabel 11.

Tabel 11. Efektivitas dalam pengambilan keputusan

\begin{tabular}{|c|c|c|c|}
\hline No. & Kode & Pembahasan & Skor \\
\hline $\mathbf{1}$ & Moora & $\begin{array}{l}\text { cukup efektif memberikan informasi } \\
\text { terkait urutan rangking proses bisnis }\end{array}$ & 4 \\
\hline 2 & SAW & $\begin{array}{l}\text { cukup efektif memberikan informasi } \\
\text { terkait urutan rangking proses bisnis }\end{array}$ & 4 \\
\hline 3 & WP & $\begin{array}{l}\text { cukup efektif memberikan informasi } \\
\text { terkait urutan rangking proses bisnis }\end{array}$ & 4 \\
\hline 4 & WSM & $\begin{array}{l}\text { cukup efektif memberikan informasi } \\
\text { terkait urutan rangking proses bisnis }\end{array}$ & 4 \\
\hline
\end{tabular}

\subsubsection{Efisiensi}

Efisiensi algoritma dimaksudkan untuk menilai kegiatan pengukuran algoritma mampu menggunakan informasi yang seminim mungkin dan proses yang cepat. Pembahasan dan penilaian tingkat efisiensi metode pengambilan keputusan dalam SPM PTMA dapat dilihat pada Tabel 12.

Tabel 12. Efisiensi dalam pengambilan keputusan

\begin{tabular}{rlcc}
\hline No. & Kode & Pembahasan & Skor \\
\hline 1 & Moora & 4 langkah proses perhitungan & 3 \\
2 & SAW & 4 langkah proses perhitungan & 3 \\
3 & WP & 3 langkah proses perhitungan & 4 \\
4 & WSM & 3 langkah proses perhitungan & 4 \\
\hline
\end{tabular}

\subsubsection{Kelebihan}

Kelebihan algoritma digunakan sebagai pertimbangan bahwa algoritma memiliki nilai lebih dibanding algoritma yang lain. Pembahasan dan penilaian kelebihan tiap metode pengambilan keputusan dalam SPM PTMA dapat dilihat pada Tabel 13.

Tabel 13. Kelebihan dalam pengambilan keputusan

\begin{tabular}{rllc}
\hline No. & Kode & \multicolumn{1}{c}{ Pembahasan } & Skor \\
\hline $\mathbf{1}$ & Moora & Ada penilaian Benefit dan Cost & 3 \\
$\mathbf{2}$ & SAW & Ada penilaian Benefit dan Cost & 3 \\
$\mathbf{3}$ & WP & $\begin{array}{l}\text { Operasi perhitungan relatif sederhana } \\
\text { dengan efisiensi tinggi }\end{array}$ & 4 \\
$\mathbf{4}$ & WSM & $\begin{array}{l}\text { Operasi perhitungan relatif sederhana } \\
\text { dengan efisiensi tinggi }\end{array}$ & 4 \\
\hline
\end{tabular}

\subsubsection{Kekurangan}

Kekurangan algoritma digunakan sebagai pertimbangan bahwa algoritma memiliki nilai yang memungkinkan untuk menjadi alasan agar diperhitungkan untuk lebih dikembangkan ke depannya. Pembahasan dan penilaian nilai kekurangan tiap metode pengambilan keputusan dalam SPM PTMA dapat dilihat pada Tabel 14.

Tabel 14. Kekurangan algoritma pengambilan keputusan

\begin{tabular}{rllc}
\hline No. & Algoritma & \multicolumn{1}{c}{ Pembahasan } & Skor \\
\hline $\mathbf{1}$ & Moora & $\begin{array}{l}\text { Proses perhitungan melalui 4 } \\
\text { langkah }\end{array}$ & 2 \\
$\mathbf{2}$ & SAW & $\begin{array}{l}\text { Proses perhitungan melalui 4 } \\
\text { langkah }\end{array}$ & 2 \\
$\mathbf{3}$ & WP & $\begin{array}{l}\text { Detail kriteria yang didefinisikan } \\
\text { minim } \\
\text { Detail kriteria yang didefinisikan } \\
\text { minim }\end{array}$ & 3 \\
\hline
\end{tabular}

\section{Kesimpulan}

Pengelompokan data standar mutu dalam bentuk basis data standar mutu disusun dengan cara membuat lebih rinci dalam butir mutu untuk selanjutnya ditetapkan indikator kinerja serta target capaian yang selanjutnya dikelompokkan kembali menjadi 11 proses bisnis PTMA, antara lain: pendidikan, pengembangan suasana akademik dan otonomi keilmuan; administrasi umum dan keuangan; perencanaan dan penjaminan mutu, serta sistem informasi; organisasi dan kerjasama; kemahasiswaan; penelitian; pengabdian kepada masyarakat; al-islam dan kemuhammadiyahan; sumber daya manusia; sarana; dan prasarana. Penggunaan metode pengambilan keputusan sebagai penentu prioritas proses bisnis menjadi informasi bagi Pimpinan PTMA dalam memprediksi kegiatan strategis. Proses Analisis telah dilakukan dan diperoleh bahwa 4 algoritma pengambilan keputusan yaitu Moora memperoleh nilai sebesar $75 \%$, SAW sebesar $75 \%$, WP sebesar 94\%, dan WSM mendapatkan nilai 94\%. Nilai tersebut mampu menjadi acuan pilihan dalam penentuan algoritma dalam metode pengambilan keputusan yang akan digunakan oleh perancang sistem informasi ke depannya.

\section{Daftar Rujukan}

[1] PP Muhammadiyah, Pedoman tentang Perguruan Tinggi Muhammadiyah. Yogyakarta: Majelis Diktilitbang PP 
Muhammadiyah, 2016.

[2] A. Nurmandi et al., Pedoman SPMI PTMA - Sistem Penjaminan Mutu Internal Perguruan Tinggi Muhammadiyah 'Aisyiyah (SPMI 4.0). Yogyakarta: Majelis Diktilitbang PP Muhammadiyah, 2019.

[3] D. Nofriansyah and S. Defit, Multi Criteria Decision Making (MCDM): pada Sistem Pendukung Keputusan. Yogyakarta: Deepublish, 2017.

[4] A. Basuki and A. D. Cahyani, Sistem Pendukung Keputusan. Yogyakarta: Deepublish, 2016.

[5] H. Pratiwi, Buku Ajar Sistem Pendukung Keputusan. Yogyakarta: Deepublish, 2016.

[6] L. A. Latif, M. Jamil, and S. H. Abbas, Sistem Pendukung Keputusan Teori dan Implementasi. Yogyakarta: Deepublish, 2018.

[7] F. Sari, Metode dalam Pengambilan Keputusan, Ed. II. Yogyakarta: Deepublish, 2020.

[8] D. Nofriansyah, Konsep Data Mining VS Sistem Pendukung Keputusan. Yogyakarta: Deepublish, 2015.

[9] Y. Lestari, Sunardi, and A. Fadlil, "Seleksi Peserta Didik Baru Menggunakan Metode AHP dan SAW," J. Sains Komput. Inform., vol. 4, no. 1, pp. 18-28, 2020.

[10] R. F. Pahlevi, Sunardi, and A. Fadlil, "Analisis Kebutuhan Sistem Informasi Data Warehouse untuk Mendukung Sistem Penjaminan Mutu Internal (Studi Kasus pada STMIK Muhammadiyah Paguyangan Brebes)," in SNST KE-9, 2018, pp. 23-27.

[11] S. R. Astari, R. Umar, and Sunardi, "Analisis dan Perancangan Sistem Pengambilan Keputusan dalam Seleksi Asisten Laboratorium," in Seminar Nasional Informatika 2018 (SemnasIF 2018), 2018, vol. 2018, no. November, pp. 13-20.

[12] D. Assrani, Mesran, R. D. Sianturi, Yuhandri, and A. Iskandar,
"Sistem Pendukung Keputusan Pemilihan Guru Produktif Peserta Pelatihan Asesor Kompetensi LSP P1 SMK Swasta Dwiwarna Medan Menggunakan Metode the Extended Promethee II (Exprom II)," KOMIK (Konferensi Nas. Teknol. Inf. dan Komputer), vol. 2, no. 1, pp. 156-166, 2018.

[13] R. Umar, A. Fadlil, and R. R. Az-Zahra, "Pengelompokan Peminatan Jurusan di SMK Menggunakan Metode Self Organizing Map (SOM)," in Seminar Nasional Teknologi dan Komunikasi - (SEMANTIKOM 2017), 2017, pp. 203-210.

[14] C. Brandas, C. Panzaru, and F. G. Filip, "Data Driven Decision Support Systems: An Application Case in Labour Market Analysis," Rom. J. Inf. Sci. Technol., vol. 19, no. 1-2, pp. 6577, 2016.

[15] I. Fajarwati, N. S. Fitriasari, and H. Siregar, "Perbandingan Metode Weighted Product (WP), Weighted Sum Model (WSM) Dan Multi Attribute Utility Theory (MAUT) Dalam Sistem Pendukung Keputusan Penerimaan Tenaga Kerja,"J. Teor. dan Apl. Ilmu Komput., vol. 1, no. 1, pp. 25-32, 2018.

[16] M. Mesran, S. Suginam, S. D. Nasution, and A. P. U. Siahaan, "Penerapan Weighted Sum Model (WSM) Dalam Penentuan Peserta Jaminan Kesehatan Masyarakat," Jurasik (Jurnal Ris. Sist. Inf. dan Tek. Inform., vol. 2, no. 1, p. 40, 2017.

17] Menristekdikti, Permenristekdikti No 62 Tahun 2016 tentang Sistem Penjaminan Mutu Pendidikan Tinggi. Indonesia, 2016, p. 8 .

DOI: https://doi.org/10.29207/resti.v5i2.2977 